\title{
NOTAS NECROLOGICAS
}




\title{
EN LA MUERTE DE SANCHEZ-ALBORNOZ
}

\author{
LUIS G. DE VALDEAVELLANO (
}

\begin{abstract}
(En imprenta ya este número ocurrio el fallecimiento del profesor García de Valdeavellano. En el próximo número tra. taremos de evaluar la magnitud de tan lamentable pérdida para nuestra ciencia y para la comunidad científica.)
\end{abstract}

Con el fallecimiento de don Claudio Sánchez-Albornoz, acaecido en Avila el pasado mes de julio de 1984, puede decirse, sin incurrir en exageración al. guna, que España ha perdido uno de sus grandes historiadores. Fue, efectivamente, Sánchez-Albornoz la última figura relevante que quedaba de un grupo de historiadores españoles que podríamos designar como la generación del Centro de Estudios Históricos, la institución fundada en 1910 por aquella Junta de Ampliación de Estudios e Investigaciones Científicas que tanto hubo de significar para el desarrollo cultural de España en el primer tercio de nuestro siglo. Discípulo de don Eduardo de Hinojosa, Sánchez-Albornoz pronto empezó a colaborar - muy joven aún - en el mencionado Centro de Estudios Históricos y a dar brillantes muestras de su talento, de sus dotes de investigador, de su vocación por la historia medieval y de su increíble capacidad de trabajo. Así, bajo la dirección de Hinojosa, Sánchez-Albornoz no tardó en dedicarse con ardor al estudio de nuestra Edad Media y, ya en 1914, publicó parte de su tesis doctoral con el título de La potestad real y los Señorios en Asturias, León y Castilla durante los siglos IX al XIII. Catedrático de Universidad desde 1918, Sánchez-Albornoz pasó en 1920 a la cátedra de Historia Antigua y Medieval de España de la Facultad de Filosofía y Letras de la Universidad de Madrid, entonces llamada "Central», y en ese mismo año, al convocarse por las Cortes españolas el concurso para optar al «Premio Nacional Covadonga», conmemorativo del centenario de la batalla y que versaba sobre el reino de Asturias y las instituciones del reino astur-leonés, Sánchez-Albornoz, estimulado a ello por don Ramón Menéndez Pidal, se dedicó a preparar una investigación sobre el tema propuesto y, con tal fin, se entregó a la tarea de recorrer los archivos de Asturias, Jaén y Galicia, en los cuales investigó incansablemente hasta ultimar la redacción de un extenso y muy documentado trabajo que fue premiado con el Premio Covadonga el año 1922. Con esta obra, Sánchez-Albornoz había dado ya en plena juventud la medida de sus cualidades de historiador, y muy especialmente de medievalista, al ilustrar con sus investigaciones y con la lucidez de su pensamiento histórico un oscuro período de la historia de la constitución político-social de España. 
La elección de don Claudio Sánchez-Albornoz como académico de la Real Academia de la Historia, en 1925, dio ocasión a que aumentase su creciente prestigio como historiador, por razón de que su discurso de ingreso en la Academia fue una obra singular en la que se aliaban la erudición del historiador y la artística forma literaria de su redacción. Sánchez-Albornoz, quien a la sazón había ya fundado en 1924, como publicación del Centro de Estudios Históricos y en memoria de su maestro Hinojosa, la prestigiosa revista Anuario de Historia del Derecho Español y dado ya a la imprenta su fundamental estudio sobre las «behetrías», aportó en su discurso de recepción académica vivas luces de conocimiento para evocar lo que era la vida de una ciudad hace mil años, con unas Estampas de la vida en León durante el siglo $X$ que, sin hipérbole, pueden ser consideradas como una pequeña joya de nuestra historiografía moderna. Pero, además, no mucho después, Sánchez-Albornoz creó en el Centro de Estudios Históricos un Seminario de Historia de las Instituciones Medievales donde se entregó con entusiasmo a su vocación de maestro, y en el cual, rodeado de discípulos, dio vida a una verdadera escuela de medievalistas. Esta escuela vino a recibir nuevos alientos cuando, por iniciativa de Sánchez-Albornoz, un decreto del Gobierno de la República creó en 1932, en el Centro de Estudios Históricos, un «Instituto de Estudios Medievales» para la publicación, bajo la dirección de don Claudio, de una gran colección de fuentes históricas españolas con el título de Monumenta Hispaniae Historica. Esta empresa se frustró, sin embargo, porque la guerra civil y la final derrota de la República obligaron a Sánchez-Albornoz a expatriarse a la República Argentina, donde pronto reanudó sus actividades docentes como profesor universitario en la Universidad de Cuyo, en Mendoza, y después en la de Buenos Aires. Con esta expatriación de Sánchez-Albornoz, que habría de durar largos, larguísimos años, se inició la fecunda etapa americana de la vida de don Claudio, quien hizo el milagro - porque milagro fue- de crear una escuela de medievalistas en la Argentina y de que sus discípulos de este país se interesasen por la historia de la España medieval y publicasen valiosos estudios acerca de nuestra Edad Media, estudios que, con otros del propio Sánchez-Albornoz y de algunos de sus discípulos españoles, han nutrido durante muchos años las páginas de la nueva revista histórica que don Claudio fundó en Buenos Aires: los Cuadernos de Historia de España. Esta revista no tardó en ser una de las mejores revistas históricas en lengua española, bajo la dirección de Sánchez-Albornoz, quien al propio tiempo dirigía en la capital bonaerense un "Instituto de Historia de la Cultura Española Medieval y Moderna».

Durante su largo destierro en la Argentina, Sánchez-Albornoz dio a la imprenta un gran número de libros y de publicaciones, resultado de su trabajo incansable. Son tantos estos libros y publicaciones que no es posible detallar- 
los sin hacer enojosa su puntual enumeración. De estos libros de Sánchez Albornoz publicados en la Argentina hay que señalar, sin embargo, su gran obra En torno a los orígenes del feudalismo, de un interés que trasciende de los límites de la estricta historia de España, en cuanto muestra no ser válida la célebre teoría del historiador alemán Brunner sobre la caballería musulmana y los orígenes del régimen feudal. Otros libros de Sánchez-Albornoz publicados en la Argentina son los titulados La España musulmana según los autores islamitas y cristianos y, sobre todo, España, un enigma bistórico, obra en la que Sánchez-Albornoz, en discrepancia con teorías de don Américo Castro, expone su pensamiento sobre las características y peculiaridades del ser histórico de España. Por otra parte, Sánchez-Albornoz, en otras obras también publicadas en América, reunió sus estudios sobre la constitución político-social de España en la Edad Media, y así lo hizo en sus libros Estudios sabre las Instituciones medievales españolas y Viejos y nuevos estudios sobre las Instituciones medievales españolas, publicando también otros trabajos en sus Estudios Visigodos y en sus Investigaciones sobre bistoriografía hispana medieval (siglos VIII al XIII). Por último, ya en la ancianidad de don Claudio, en España fueron publicados dos de sus libros más importantes. Así, el Instituto de Estudios Asturianos publicó los tres gruesos volúmenes de Orígenes de la Nación Española. Estudios críticos sobre la Historia del Reino de Asturias, y la Editorial Espasa-Calpe dio a la estampa, formando parte de la Historia de España fundada por Menéndez Pidal, el libro titulado El Reino astur-leonés (722-1037). Sociedad, Economia, Gobierno y Vida, que en realidad no es sino la reelaboración de parte de la primera obra del maestro que aún permanecía inédita: la premiada en 1922 con el Premio Covadonga.

Seguramente lo que más puede interesar a los lectores de esta revista es la referencia aquí a las aportaciones que las investigaciones de Sánchez-Albornoz han significado para el mejor conocimiento de la historia económica de España en la Edad Media. Así, por lo que se refiere al reino astur-leonés, Sánchez-Albornoz supo indagar acerca de su régimen económico, descubriendo en los documentos astur-leoneses de los siglos $\mathrm{Ix}$ y $\mathrm{x}$ cuál era el régimen de la tierra e ilustrándonos sobre la agricultura, la industria y el comercio en esos siglos y acerca de la moneda de cambio y la moneda de cuenta y los precios, de los que Sánchez-Albornoz ha conseguido establecer algunos cuadros estadísticos de los siglos x y xI. Don Claudio ha estudiado también los contratos agrarios de plantación y de cultivo y el sistema de explotación agraria de las grandes propiedades territoriales o señoríos, o sea, del llamado régimen señorial. Asimismo, Sánchez-Albornoz puso de relieve cómo en el reino asturleonés se dio cierta actividad comercial y que a la ciudad de León en el siglo x llegaban telas y armas procedentes de la España musulmana, de Francia, del Imperio bizantino y de la lejana ciudad persa de Doshtowa, famosa por su 
industria textil, mercancías todas ellas que se vendían en el mercado público que en León se reunía semanalmente todos los miércoles: precisamente este mercado fue evocado por Sánchez-Albornoz en una de sus animadas estampas de la vida en León durante el siglo $\mathrm{x}$. Y don Claudio mostró también la temprana aparición en León de un comercio permanente, al comprobar en los documentos leoneses la existencia de algunas tiendas en el León de hace mil años.

Una aportación fundamental de Sánchez-Albornoz a la historia económica y social de España es, sin duda, la de haber mostrado cómo las especiales circunstancias históricas determinadas por la Reconquista cristiana del territorio, al originar la despoblación del valle del Duero y determinar una forma singular de realizarse su repoblación en los siglos ix y x mediante la libre apropiación privada de las tierras desiertas y yermas por labriegos carentes de recursos, hubo de dar origen al particular fenómeno de la formación de numerosas pequeñas propiedades territoriales y de muchos propietarios rurales de condición social libre, de lo cual derivaría que no llegase a desarrollarse en la mayor parte de España un verdadero régimen feudal. La cuestión de la despoblación del valle del Duero es básica en la obra y el pensamiento históricos de SánchezAlbornoz, y a ella dedicó éste un extenso y documentadísimo libro que tituló Despoblación y repoblación del valle del Duero.

Sánchez-Albornoz ha mostrado también las consecuencias de la crisis agrícola del siglo xiri, originada por las grandes conquistas territoriales de Fernando III, crisis que determinó en Castilla escasez de mano de obra, descenso de los rendimientos de la economía agraria y consiguiente alza de los precios agrícolas. Esta crisis fue aprovechada por los mercaderes flamencos para importar a Castilla toda clase de mercancías para suplir la escasa producción artesana de las ciudades castellanas, insuficiente para el abastecimiento del país. En el reinado de Alfonso X se agudizó la crisis económica y se inició un proceso inflacionario que no se detendrá ya hasta el reinado de los Reyes Católicos. Por otra parte, Sánchez-Albornoz supo poner de relieve lo que fue la política económica de Alfonso el Sabio, la que Sánchez-Albornoz denominó «política económica dirigida» de ese rey de León y Castilla.

Pero Sánchez-Albornoz no solamente fue un gran historiador, sino también un gran patriota y un gran liberal. Durante su larguísimo destierro en la Argentina, Sánchez-Albornoz vivió obsesivamente la nostalgia de España y soñó con el regreso. Apasionado por la libertad, cuando la Academia dei Lincei de Roma le otorgó el Premio Feltrinelli, únicamente concedido a los grandes historiadores, el tema de su discurso de gracias fue precisamente el de Historia y Libertad. 